MAREK PAWEŁCZAK

https://orcid.org/0000-0001-8608-2147

Uniwersytet Warszawski

\title{
STATISTICAL DATA ON INTERNATIONAL TRADE IN BRITISH CONSULAR REPORTS FROM THE SULTANATE OF ZANZIBAR IN THE NINETEENTH CENTURY ${ }^{1}$
}

Zarys treści: Niniejszy artykuł skupia się na kwestii wiarygodności dziewiętnastowiecznych brytyjskich raportów konsularnych jako źródeł w badaniach handlu międzynarodowego w Zanzibarze. Autor zestawia ze sobą dane statystyczne zawarte w wyżej wymienionych dokumentach z pochodzącymi z raportów francuskich i amerykańskich, a także z korespondencja amerykańskich i niemieckich przedsiębiorstw handlowych prowadzących działalność w Zanzibarze. Analiza pokazuje, że dane ujęte w brytyjskich raportach pochodzą z generalnie wiarygodnych źródeł, które jednak udostępniane były jedynie w okresach spadku koniunktury. Chociaż $\mathrm{w}$ statystykach pojawia się niewiele nieścisłości, to prawdopodobne jest, że dane były znacząco zaniżane. Nie wyklucza to jednak dużego stopnia wiarygodności raportów w odzwierciedlaniu struktury lokalnego handlu i najważniejszych tendencji w nim występujących.

The content outline: The article concerns the reliability of nineteenth-century British consular reports as a source for the study of international trade in Zanzibar. The author confronts the statistical data contained therein with reports from France and the United States, as well as with the correspondence of US and German trade companies operating in Zanzibar. The author concludes that the data contained in the reports derives from essentially reliable sources, access to which, however, was only possible in the years of economic downturn. Although few inconsistencies can be found in the statistics, it is likely that they include significant underestimations. However, this does not preclude a significant degree of credibility in terms of the structure and general trends of the trade.

Słowa kluczowe: Afryka Wschodnia, Zanzibar, źródła, XIX w., handel międzynarodowy, raporty konsularne

1 Archival research for this article was made possible thanks to a grant from the Polish National Science Center (grant number 2015/19/B/HS3/01747). 
Keywords: East Africa, Zanzibar, sources, nineteenth century, international trade, consular reports

\section{Introduction}

In the nineteenth century, Zanzibar, formerly only known as hub for the slave trade, became the capital of a local empire: first the MuscatZanzibar state founded by Sa‘īd bin Sulțān Āl Bu Sa'īdi (1806-1856), and then, from the 1860s, the Sultanate of Zanzibar. Under Sa'îd's rule, Zanzibar gained importance as a thriving trade centre for products delivered by way of East African caravan routes, as well as industrial goods imported from overseas. The gradual reduction of slave trade was accompanied by an increase in the trade of products offered by the African continent, such as ivory, copal, rubber, animal skins or the local plant known as orchilla, from which indigo dye is obtained. While industrial goods had been imported by Africa for centuries, the trade boom during the independent Sultanate of Zanzibar epoch introduced the region into the era of modernity and globalisation even before the imperial conquest of the 1880 s and 1890 s. $^{2}$

Regardless of shifts in interest within the field of African history, thorough knowledge of the Zanzibar trade remains an indispensable context for reflections on the transformation of culture, society and religion in East Africa, as well as on larger scale issues, such as imperialism, European expansion, intercontinental migration and cultural connectivity. ${ }^{3}$ The first wave of interest in the history of pre-colonial Africa, which dates back to the 1960s and 1970s, produced the initial works on the Zanzibar trade, the most important of which are the books of Christine Nicholls and Abdul Sheriff, which concerned the period up to 1856 and to 1873 , respectively. ${ }^{4}$ The dispersion of the source base among four

${ }^{2}$ An article on this subject will be published soon by this author. See: "Customs house, steamers and the entrepôt. Zanzibar trade infrastructure circa 1830-1888," African Economic History, 48, 2020, No. 2.

${ }^{3}$ E. Gilbert, Dhows and the Colonial Economy of Zanzibar: 1860-1970, London, 2004; F.A. Bishara, A Sea of Debt: Law and Economic Life in the Western Indian Ocean, c. 1780-1950, Cambridge, 2017; T. McDow, Buying Time: Debt and Mobility in the Western Indian Ocean, Athens (OH), 2018; P. Machado, S. Fee, G. Campbell, Textile Trades, Consumer Cultures and the Material Worlds of the Indian Ocean: An Ocean of Cloth, Cham, 2018; A.K. Bang, Sufis and Scholars of the Sea: Family Networks in East Africa, 1860-1925, London, 2003.

${ }^{4}$ Ch.S. Nicholls, The Swahili Coast: Politics, Diplomacy and Trade on the East African Littoral 1798-1856, London, 1971; A. Sheriff, Slaves, Spices and Ivory in 
continents, in at least six countries, has not yet allowed any researcher to comprehensively analyse the Zanzibar trade in the period from 1873 to 1888 . Sheriff's work, which was written in the 1970s, has not led to subsequent studies. One of the reasons for this is certainly the departure from the use of quantitative methods in African historiography. There is not enough room here to consider the grounds for this change, among which one could undoubtedly indicate general trends in historiography. However, the growing interest in global history in recent years justifies the return to the theme of nineteenth-century Zanzibar trade. Without a thorough knowledge of its trends, exchange structure and infrastructure, especially related to the capital market, one cannot properly apply a global perspective to nineteenth-century East Africa. ${ }^{5}$

This requires, inter alia, reflection on the reliability of the sources for statistical data, which is a neglected area of research. ${ }^{6}$ While the state of the statistics from most of pre-colonial sub-Saharan Africa leaves much to be desired, Zanzibar is one of the few exceptions. We have statistical data produced by the British, French and US consulates from the 1850 s to independence (1890), although not all periods are represented equally in the documents. This article focuses on administrative and commercial reports prepared by British diplomatic representatives in Zanzibar in the years 1860-1887. Historians have consulted them for an extensive period as the most important source for both the political and socio-economic history of Zanzibar, usually excluding similar French and US sources. This is justified by the fact that British reports tend to be extensive, more freeform documents that combine political, social and economic themes. They also concern, as a rule, global trade, without being limited to data on the activities of domestic merchants and the conditions in which they operated. The latter shortcoming applies largely to US reports, and to a lesser extent the those from France.

This article aims to verify the reliability of the statistical data contained in the British reports on Zanzibar. It is limited to general exports and imports, both globally and in relation to selected countries that traded with Zanzibar, that is, British India, France and the US. It does

Zanzibar: Integration of an East African Commercial Empire into the World Economy, 1770-1873, London, 1987.

5 J. Prestholdt, Domesticating the World. African Consumerism and the Genealogies of Globalization, Berkeley, 2008.

6 The only extensive work on statistical sources for the pre-colonial African trade is "Figuring African Trade: Proceedings of the Symposium on the Quantification and Structure of the Import and Export and Long Distance Trade in Africa, 1800-1913," ed. by G. Liesegang, H. Pasch, A. Jones, in: Kölner Beitrage zur Afrikanistik, 11, 1986. 
not address specific categories of goods such as ivory or the firearms trade, which would require further research. ${ }^{7}$ In connection with its central theme, the article attempts to assess the difference between the reliability of data on imports and exports, and establish whether they changed over time. Data on exports, although considered by the consuls to be generally less reliable than data on imports, comes, unlike the latter, from various sources, which allows verification of their consistency. As the reports were not written regularly, the article explores the availability of primary sources used by their authors, including Zanzibar customs books. It asks how much their availability was related to the economic situation and circumstances related to the renewal of the five-year Customs farming contract, which is also of relevance. To this end, all available data on the global imports and exports of Zanzibar in the period under consideration is compiled to identify periods of greater or lesser prosperity. This is based solely on the value of trade, because data on the quantity of imported and exported goods occurs rarely in the analysed reports. Since the British reports were not the only ones to contain statistical data, it is reasonable to ask whether the authors of the French and US reports used the same sources and whether multiple borrowings of data took place.

In line with this topic, the most important sources for this article are British reports. They are the most complete among diplomatic reports. Furthermore, the data they contain were created independently of these compiled by other consulates, with the occasional exception of data concerning specific countries: for example, the US Consulate statistics on US trade might have been used by the British consul as the main source on the subject. In contrast to the British reports, the analysis of French and US reports is limited to trade figures, their conformity with other data and the forms of data presentation. US and French reports are also used to supplement the source material whenever they contain data for periods missing in the British documents. Moreover, they are valuable for comparison of the data on the volume of global trade and the trade of each of specific countries, viz. Britain, France and the US. This enables researchers to identify instances of data borrowing and assess the reliability of estimates made by specific consulates.

The present analysis relies on the most complete versions of the relevant documents, usually manuscripts, with the exception of the report by George Seward (in office 1865-1867) from 1865, whose manuscript

${ }^{7}$ I. Hahner-Herzog, Tippu Tip und der Elfenbeinhandel in Ost- und Zentralafrika im 19. Jahrhundert, München, 1990. 
could not be located in British or Zanzibari archives. Fortunately, this report has been very carefully published in the British Parliamentary Papers. Only in the case of US reports are published versions consulted, provided they contain fragments removed from the manuscript version. This does not apply to the reports of William Speer from 1862 and of Edward D. Ropes from 1865, for which only manuscript versions were used. The full catalogue of British, US and French reports and the versions quoted herein, along with the abbreviations used in footnote references and in the main text, are to be found at the end of the article.

In the nineteenth century, the degree of professionalisation of Western consular posts varied. Not all British consuls were paid a salary, for example: some were merchants or agents who performed consular duties while working for commercial firms. Serving as consul provided hope for commercial agents seeking to improve their social status and, as a consequence, offered greater business opportunities. Similarly, in US diplomacy the majority of consular staff did not receive a salary. ${ }^{8}$ Moreover, all North German consuls in Zanzibar (the German Reich took control of the de facto Hamburg consulate only in 1885) and most of the US consuls until 1886 were merchants conducting their own business or representing other companies. ${ }^{9}$ This contrasted with the case of French diplomats: the position of the French consul in Zanzibar was political, even if the person who held the post was also a professional in commerce. ${ }^{10}$

As the nineteenth century progressed, Western diplomatic missions were obliged to inform their governments about the state of foreign trade in the cities or countries in which they operated. The French consuls prepared reports on French and foreign trade and shipping in accordance with the decree of $1833 .{ }^{11}$ These reports had a much more standardised form than British and US reports, but they contained almost exclusively bare statistical data. In 1835, the Committee of the House of Commons for Consular Missions recommended that instructions for consuls include the requirement to submit full commercial reports to their superiors at least every six months. ${ }^{12}$ As a result, however, only

${ }^{8}$ F. de Goey, "Consuls and the Institutions of Global Capitalism, 1783-1914," Perspectives in Economic and Social History, 2016, No. 34, p. 18.

${ }^{9}$ F. de Goey, op. cit., pp. 24-25.

${ }^{10}$ A. Mézin, "Les services consulaires français au XIX siècle," in: Consuls et service consulaires au XIXe siècle. Consulship in the $19^{\text {th }}$ Century. Die Welt der Konsulate im 19. Jahrhundert, ed. by J. Ulbert, L. Prijac, Hamburg, 2010, p. 49.

${ }_{11}$ A. Mézin, op. cit., pp. 49-50.

${ }^{12}$ F. de Goey, op. cit., p. 18. 
the commercial reports from Western and major non-European countries were prepared. They were published, among others, in the British Parliamentary Papers, as well as Confidential Prints printed for the Foreign Office. ${ }^{13}$ Emphasis on producing regular and reliable commercial reports increased with the global economic depression of the 1870s, which involved a dip in colonial exports and increased competition from Germany. While the quality of these reports improved, they still did not arrive regularly from all diplomatic posts. The US Department of State treated the issue of reports more freely than the ministries of the other two countries in question. Only in 1868 did the US Congress decide to publish them. Like their British equivalents, US reports have not always been up-to-date, and the reliability of the information contained therein sometimes leaves much to be desired. ${ }^{14}$

The British consular post in Zanzibar was created in 1841 after the signing of the Treaty of Friendship and Trade between Great Britain and the Muscat-Zanzibar State in 1839. The US consulate was established slightly earlier (1839), followed by those of France (1846) and Hamburg (1857). All these countries signed treaties with Zanzibar that contained a mutual most-favoured-nation clause and provided for a flat, $5 \%$ customs duty on imported goods. Unlike the US and Hamburg consulates, the position of British consul and political agent of the Bombay Presidency in Zanzibar was professional and political. The dual nature of the position affected all consular activities, including the content of the reports. As representatives of the Foreign Office, the consuls mainly dealt with issues related to combatting slave trade, which was the focus of London's interest in the region. As representatives of the British government in Bombay, however, consuls primarily managed the affairs of Indians settled in East Africa.

The lack of personal involvement in commercial matters meant that the reports of British consuls were often less competent than those of their US colleagues. Some aggregate data was presented carelessly, which can only be determined if a report contains detailed data on specific categories of goods. Usually, the British Zanzibar consulate employed former military personnel or administrators serving in India and the Persian Gulf, such as Christopher Rigby, Robert Playfair and George Seward. This does not apply to the author of two important reports from the 1870s, probably the most prominent British consul in Zanzibar - John Kirk (1870-1880), who was a botanist and

\footnotetext{
${ }^{13}$ For details, see the Catalogue of Reports at the end of this article.

${ }^{14}$ F. de Goey, op. cit., pp. 25-26.
} 
a distinguished explorer of Africa. Among British consuls, Kirk, despite having little to do with trade or shipping, was most interested in economic issues. He was also probably in favour of placing Zanzibar and the East African coast under some form of British protectorate and conducted certain behind-the-scenes activities to that effect. ${ }^{15}$

Indians, who controlled a large percentage of Zanzibar's international trade, were of particular interest to British consuls on the island. ${ }^{16}$ In almost every report, the authors referred to the high position and role of the Indian community in the local economy. They usually discussed the volume of Zanzibar's trade with Great Britain jointly with that of British India and the British protectorate of Kutch (the latter occasionally labelled the 'protected States of India'), because the share of Great Britain at the beginning of the period in question was small or non-existent (see Table 4). Merchants from Great Britain were present in Zanzibar in the 1830s and the early 1840s. Then, until around 1863, all trade between Great Britain and East Africa was carried out exclusively through Indian hands. Perhaps that is why Atkins Hamerton, who served as the British consul in 1841-1857, never prepared a commercial report. Only French and US reports are available for the period after the 1850s. Their statistical content is limited to trade with their own country or, to a certain extent, other Western countries. The author of the first British consular report from Zanzibar was Colonel Christopher Rigby, the consul in the years $1859-1861 .{ }^{17}$ He focused on attempts to bring British Zanzibar immigrants from India under British jurisdiction. The purpose of these actions was to deprive them of slaves in accordance with British India law and the imperial policy of the era. Rigby managed to implement his plan only partially. ${ }^{18}$ In addition, his report should be viewed in the context of the political turnaround that followed the repression of the Great Uprising in India. Starting from 1859 , the British authorities in India appreciated the importance of

15 J.S. Galbraith, Mackinnon and East Africa 1878-1895: A Study in the 'New Imperialism', Cambridge, 2009, pp. 370-376.

${ }^{16}$ National Archives in London (hereinafter: NA), FO/84/1415, Prideaux to Earl Derby, 8 Feb 1875, f. 202-256 (hereinafter: HOLMWOOD). For the abbreviations, bibliographic entries in full capital letters and the bibliographical details of all reports used, see the Catalogue of Reports at the end of the article.

${ }^{17}$ British Library in London (hereinafter: BL), IOR/L/PS/9, vol. 37, Ch. Rigby to Earl Russell, 1 Jul 1860 (hereinafter: RIGBY), f. 597-655.

${ }^{18}$ H. Suzuki, "Enslaved Population and Indian Owners Along the East African Coast: Exploring the Rigby Manumission List, 1860-1861," History in Africa, 39, 2012, pp. 209-239; Ch.P. Rigby, General Rigby, Zanzibar and the Slave Trade: With Journals, Dispatches etc., ed. by Ch.E.B. Russell, London, 1935. 
Indian trade, including trade on traditional sailing boats, although consuls had no idea of their number or the total tonnage they represented. ${ }^{19}$

Rigby's report is a rather extensive text compared to similar documents from the 1860s. It contains information on geography, natural conditions, history, politics, demography, culture, health and economy, including transport and commerce. The US consul William Speer (1861-1863), critically evaluating Rigby's statistical data, admitted that his report had broken with the widespread practice of scaring potential newcomers away from the island. ${ }^{20}$ At the same time, however, Rigby did not avoid stereotyping the Omani Arabs in Zanzibar. He characterised them as "lazy, ignorant liars and arrogant cowards," and warned against leaving the island in their hands. Rigby contrasted this racist view of the Arabs with the information about the growing role of Indians, "through whom almost all foreign trade passes." 1

Successive authors of the reports synthesised data from customs books to make the process more transparent. After Rigby, the next two reports were prepared by Colonel Robert Playfair (in office 1863-1865). The first document is dated 1863 and contains a short introduction as well as data for the financial years 1861/62 and 1862/63. ${ }^{22}$ The second Playfair report, of 1864, contains almost exclusively statistical data for the years 1862/63 and 1863/64. ${ }^{23}$ His successor in office, Consul George Seward, took on a more difficult task when preparing his report for the year $1865,{ }^{24}$ and compiled a thorough summary of data from all previous British reports, also including the original data for $1864 / 65$. Due to the American Civil War, the beginning of the 1860s marked a crisis in the Zanzibar trade. In his first report dated 1863, Playfair emphasised the role that British products played on the local market. ${ }^{25}$ Seward presented a similar narrative in his report from 1865, noting that

19 RIGBY (c), f. 345.

${ }^{20}$ National Archives and Records Administration, Washington DC, US (hereinafter: NARA), Dispatches from U.S. Consuls Zanzibar, 1836-1906, microcopy 468 (hereinafter: USCZ), reel 2, W. J. Speer, Consular Report, 26 Nov 1862 (hereinafter: SPEER).

${ }^{21}$ RIGBY (c), f. 346.

${ }^{22}$ BL, IOR L/PS/9/41, Playfair to Russell, Administration Report of the Zanzibar Political Agency for the Year Ending 31 May 1864, 1 May 1864 (hereinafter: PLAYFAIR1).

${ }^{23} \mathrm{BL}$, IOR L/PS/9/42, R. Playfair to C. Gonne, Administration Report of Zanzibar for the Year 1864-64, 17 Apr 1865 (hereinafter: PLAYFAIR2), f. 881-893.

${ }^{24}$ House of Commons, British Parliamentary Papers (hereinafter: PP), 1867, 3761, Report by Mr. Acting Consul Seward on the Trade and Commerce of Zanzibar for the year 1864-5 (hereinafter: SEWARD), f. 281-288.

${ }^{25}$ PLAYFAIR1 (b), p. 180. 
Hamburg merchants were importing British textiles. ${ }^{26}$ However, Seward's most important observation was the increase in the role of British shipping in Zanzibar's international trade between 1855 and $1865 .^{27}$

British data from the 1860s can be compared with those contained in the French and US reports from the same period. While the British consuls mainly used sources that are now lost, i.e. customs books, their French and US colleagues consulted documents that are partially available in the archives, in the form of quarterly or trimester-based accounts of ship traffic that listed the cargo and value of transported goods. The reports of the French consulate between 1862/63 and 1867/68 are particularly valuable because they fill the gaps in British data, whereas the previous records are limited to data on the trade of Western countries present in Zanzibar and only include several categories of goods. ${ }^{28}$

The first two British reports written in the 1870s resemble the Rigby document, as they contain a variety of data and a wealth of socio-political context. The 1870 report by John Kirk is more extensive than those of Playfair and Seward, though not as extensive as the Rigby report. As indicated in Table 4, the share of India's and Great Britain's Zanzibar trade decreased in 1867/68 compared to the first half of the 1860s. Kirk emphasised that the combined volume of imports of Great Britain, British India and Kutch was almost thrice as much as the next country on the list, namely Hamburg, even if British goods were imported by ships from Hamburg and France. ${ }^{29}$ The report of Vice-consul Frederick Holmwood, which contains data from the years $1872 / 73$ and $1873 / 74,{ }^{30}$ overlooked the obvious decline in the share of British and Indian trade in total Zanzibar trade. ${ }^{31}$ In the next report, its author John Kirk did not have to confront a similar problem, as he was reporting on a period of booming trade. ${ }^{32}$ This concise document does not contain detailed lists of imported goods, but only aggregated data on the import and export of

26 "Indirect trade has been very considerable; two thirds of the Hamburg imports are said to issue from the marts of Great Britain. The whole of the cotton fabrics imported, save perhaps for an unimportant contribution from Muscat, may be looked upon as of British manufacture and the coal imports are wholly from Wales.” SEWARD, f. 285.

27 SEWARD, f. 285.

${ }^{28}$ The authors are Ladislas Cochet, Maurice Derche, Henryk Jabłoński and Eugène Bure (see: The Catalogue of Reports).

${ }^{29} \mathrm{NA}, \mathrm{FO} / 84$ 1344, J. Kirk, Administration report of the Zanzibar Agency, 1870, Rendered July 18, 1870, f. 116-166 (hereinafter: KIRK1).

30 HOLMWOOD.

${ }^{31}$ HOLMWOOD, f. 229.

${ }^{32} \mathrm{NA}, \mathrm{FO} / 84 / 1657$, Report by Consul Kirk on the trade and Commerce of Zanzibar for the year 1881, 21 Apr 1882, f. 11-24 (hereinafter: KIRK2). 
specific categories of goods without naming the countries and regions to which they relate. The most eye-catching motif of Kirk's second report is the statistically evidenced superiority of British shipping over the merchant fleets of other countries. The observation is confirmed in the report by the US Consul Leonard Bachelder (in office 1880-1883) of 1881, who attributed this to the disadvantage of US merchants, who for many years had occupied a leading position in East African trade..$^{33}$

In the era of steamers, which only began in Zanzibar when the first regular shipping route to Aden opened in 1872, freight on routes from Zanzibar to Europe decreased significantly. ${ }^{34}$ The lack of data on imports and exports by country in the report of 1881 should also be attributed to the transport revolution. This position had been included in every report to date. The triumph of steamers, with their cargo capacity much higher than that of sailing ships, loosened the links between the country of origin and the destination of a good, nationality of the merchant and the means of transport. Not only the British, but also Indians were selling goods from Zanzibar on the London market. The Hamburgers were supplying Zanzibar with British goods and were using British steamers when sending African goods to Hamburg. The French were sending goods to Bombay on ships belonging to the Sultan of Zanzibar. ${ }^{35}$

John Kirk noted these changes in his 1881 report. His journal entries show that he knew much more than he revealed in his official report about the trade conducted by Zanzibari Indians with Europe and the US without the brokerage of Western agents. Nor did he disclose this knowledge in consular correspondence. The increase in the role of Zanzibari Indians in Zanzibar imports is illustrated by Table 1 below. It indicates that the share of their companies in Zanzibar imports between 1859/60 and $1876 / 77$ increased from just over $30 \%$ to nearly $50 \%$. One reason why Kirk may have abstained from publishing his data could have been his fear that once London knew how Indians used the 'mail' steamship line, the British government could withdraw from subsidising it. The line was operated by a company belonging to Kirk's friend, William Mackinnon. ${ }^{36}$

${ }^{33}$ L. Bachelder, "Trade of Zanzibar," in: House of Representatives, Report upon the Commercial Relations of the United States with Foreign Nations for the Years 1880 and 1881, Washington, 1882 (hereinafter: BACHELDER), p. 36.

${ }^{34}$ O'Rourke and Williamson considered the freight reduction caused by the transport revolution as a major factor in nineteenth-century globalisation. K.H. O'Rourke, J.G. Williamson, Globalization and History: The Evolution of a Nineteenth-Century Atlantic Economy, Cambridge (MA), 2000, pp. 43-53.

${ }_{35}$ The Kirk report from 1870 already points out that ships from France and Hamburg were also importing British goods. KIRK1, f. 120.

36 J.S. Galbraith, op. cit., pp. 438-452. 
Table 1: Comparison of the value of goods imported into Zanzibar by Indian and Western companies in 1859/60 and 1876/77, expressed in Maria Teresa thalers (MTT 1 was approximately equal to USD 1) ${ }^{37}$

\begin{tabular}{|l|c|c|}
\hline \multirow{2}{*}{ Company origin } & \multicolumn{2}{|c|}{ Fiscal year } \\
\cline { 2 - 3 } & $\begin{array}{c}\mathbf{1 8 5 9 / 6 0} \\
\text { (MTT) }\end{array}$ & $\begin{array}{c}\mathbf{1 8 7 6 - 7 7} \\
\text { (MTT) }\end{array}$ \\
\hline British India and Kutch & 708,654 & $1,469,980$ \\
\hline Western countries & $1,541,178$ & $1,487,960$ \\
\hline
\end{tabular}

The latest official British report about the volume of Zanzibar trade in the independence era was penned by Acting Consul Claude M. MacDonald. It is dated to 1887 and contains very scarce data on international trade in the financial year 1885/86. It follows the narrative of the supremacy of British trade noted in the second Kirk report and acknowledges the common thread of the reports of the 1860s i.e. the commercial success of India and Great Britain. However, the author no longer conceals the absolute advantage of Indian merchants over those of other nations. ${ }^{38}$ This is particularly significant due to the fact that the colonial division of the East African coast had already been settled by $1887,{ }^{39}$ and the predominance of the Indians also extended to the hinterland area, which was soon to come under German control.

Earlier, the process of dividing East Africa had been referenced in a letter from Acting Consul in Zanzibar Frederick Holmwood to the President of the Chamber of Commerce in Manchester, James Hutton. The letter, which has the characteristics of a comprehensive commercial report, was published in British press in April 1885. ${ }^{40}$ Holmwood was extremely optimistic about East African trade prospects. Unlike official reports, he used, in a strongly manipulative way, contemporary knowledge about societies in the interior. However, when it comes to foreign trade, the author employed outdated, although officially the most recent available, data for 1876-1879 taken from Kirk's second report. This may be due to the crisis in trade that occurred on the coast

${ }^{37}$ Rigby uses this conversion although he declares that the pound exchange rate is from MTT 4.5 to 4.75. RIGBY, f. 654; Kirk Diary, file 35, 12 May 1878.

${ }^{38}$ NA, FO/403/104/10, Major C.M. MacDonald to Marquis Salisbury, 19 Dec 1887 (hereinafter: MACDONALD). For a similar argument made by Abdul Sheriff, see id., op. cit., pp. 105-108.

${ }^{39}$ N. Bennett, A History of the Arab State of Zanzibar, London, 1978, p. 132.

${ }^{40}$ NA, FO 881/5732, Frederick Holmwood, Zanzibar and East African Trade, 1885. Reply to Letter addressed to Consul Holmwood by Mr. James F. Hutton, President of the Chamber of Commerce of Manchester, 10 Apr 1885. 
in 1883-1884 due to famine and the bankruptcies of two large trading companies, which put a damper on the moods prevailing among the Zanzibar merchant community. ${ }^{41}$

In the period between the publication of the first British report of 1860 and the end of independence, the British consuls prepared only seven full commercial reports containing data on imports from 11 years, and on exports from ten years (not counting MacDonald's micro-report). Scarce data on Zanzibar trade from the 1880s can be supplemented to some extent with data from US reports, including that of Francis Webb (1869-1872) for 1870/71, aforementioned Leonard Bachelder for 1880/81 and Frederick Cheney (1882-1886) for the year 1883/84. Although the author of the last report questioned its credibility himself, ${ }^{42}$ it contains aggregate data on Zanzibar trade unavailable in other documents.

Table 2: The volume of the international trade of Zanzibar calculated in MTT (excluding bullion and specie) ${ }^{43}$

\begin{tabular}{|l|c|c|c|}
\hline Fiscal year & Imports & Exports & Total \\
\hline 1859 & $1,702^{\mathrm{r}+}$ & $1,799^{\mathrm{r}}$ & 3,501 \\
\hline $1861 / 62$ & $943^{\mathrm{p} 1}$ & $988^{\mathrm{p} 1}$ & 1,931 \\
\hline $1862 / 63$ & $1,144^{\mathrm{p} 1}$ & $1,102^{\mathrm{p} 1}$ & 2,246 \\
\hline $1863 / 64$ & $1,128^{\mathrm{p} 2}$ & $2,219^{\mathrm{p} 2}$ & 3,347 \\
\hline $1864 / 65$ & $1,324^{\mathrm{sw}}$ & $1,429^{\mathrm{sw}}$ & 2,753 \\
\hline
\end{tabular}

${ }^{41}$ PEM, RE, box 55, Cheney to Arnold Hines \& Co. and Ropes Emmerton \& Co., 28 Jan 1884, f. 3; Staatsarchiv Hamburg (hereinafter: STAH), Familie O'Swald, (hereinafter: FO), Bd. 36, 621-1/147/4, O'Swald to O'Swald \& Co., 7 Jul 1885.

42 "Modesty forbids me from naming the author of the great trade report, but if you knew as much about it as I do you wouldn't take much stock of it," "E.D. Ropes Jr. to E.D. Ropes, 15 Nov 1884," in: E. Ropes, The Zanzibar Letters of Edward D. Ropes, Jr., ed. by N. Bennett, Boston, 1979, p. 41. According to Norman Bennett, the editor of Ropes's letters, the above passage suggests that it was him and not Consul Cheney who was the actual author of the 1884 report. ibid.; NARA, USCZ, reel 4, Cheney to Third Assistant of the Secretary of State, 1 Jul 1884 (hereinafter: CHENEY).

${ }^{43}$ In the years 1870 and 1875, unlike in previous reports, specie was not included in the balance. According to Frederick Holmwood, US companies brought $\$ 600,000$ in gold in the fiscal years $1872 / 73$ and $1873 / 74$. The table contains data compiled from British, US and French sources. I have consulted all available British data and, where they are missing, US and French data. Aggregated data in British reports are given in pounds sterling, and in French reports in French francs. The currency of the Sultanate was the Maria Teresa thaler (MTT). The following conversion rates were used: MTT $1=$ USD 1; until 1870 GBP $1=$ MTT 4.5; After 1871, GBP $1=$ MTT 4.75. For the French franc: for the years 1859-1862: MTT $1=$ FRF 5.2; for the years 1863-1865 MTT $1=$ FRF 5.5; after 1866, MTT 1 = FRF 5.3. 


\begin{tabular}{|l|c|c|c|}
\hline Fiscal year & Imports & Exports & Total \\
\hline $1865 / 66$ & $1,208^{\mathrm{f} 66}$ & $1,599^{\mathrm{f} 66}$ & 2,807 \\
\hline $1866 / 67$ & $1,710^{\mathrm{f} 67}$ & $2,367^{\mathrm{f} 67}$ & 4,077 \\
\hline $1867 / 68$ & $1,953^{\mathrm{k} 1}$ & $1,856^{\mathrm{k} 1}$ & 3,819 \\
\hline $1870 / 71$ & $1,277^{\mathrm{w}}$ & $2,396^{\mathrm{w}}$ & 3,673 \\
\hline $1872 / 73$ & $1,617^{\mathrm{hm}}$ & $1,740^{\mathrm{hm} *}$ & 3,357 \\
\hline $1873 / 74$ & $1,877^{\mathrm{hm}}$ & $1,216^{\mathrm{hm} *}$ & 3,093 \\
\hline $1876 / 77$ & $3,303^{\mathrm{k} 2}$ & $4,379^{\mathrm{k} 2}$ & 7,682 \\
\hline $1877 / 78$ & $3,268^{\mathrm{k} 2}$ & $4,859^{\mathrm{k} 2}$ & 8,127 \\
\hline $1878 / 79$ & $3,372^{\mathrm{k} 2}$ & $4,132^{\mathrm{k} 2}$ & 7,504 \\
\hline $1880 / 81$ & $3,000^{\mathrm{b}}$ & $2,500^{\mathrm{b}}$ & 5,500 \\
\hline $1883 / 84$ & $2,200^{\mathrm{ch} @}$ & $4,000^{\mathrm{ch}}$ & $6,200^{\varrho}$ \\
\hline $1885 / 86$ & $3,400^{\mathrm{mc}}$ & $5,050^{\mathrm{mc}}$ & 8,450 \\
\hline
\end{tabular}

* Amount of imports from the coast and Pemba. The value of cloves from Zanzibar was negligible due to the hurricane of April 1872, which destroyed most of the island's plantations; ${ }^{\circledR}$ Calculated amount ${ }^{44} ;+$ This probably refers to the year $1859 / 60$.

Table 3: Income of the Zanzibar Customs (in thousands of MTT) ${ }^{45}$

\begin{tabular}{|c|c|}
\hline Fiscal year & Customs income \\
\hline $1870 / 71$ & $311^{\mathrm{w}}$ \\
\hline $1879 / 80$ & 870 \\
\hline $1880 / 81$ & 1,090 \\
\hline $1881 / 82$ & 1,110 \\
\hline $1882 / 83$ & 1,011 \\
\hline $1883 / 84$ & 925 \\
\hline
\end{tabular}

${ }^{44}$ The report of E.D. Ropes Sr. of 1865, citing the customs books of Zanzibar, provides the number MTT 6,100,000. This amount undoubtedly includes imports from the East African coast and Pemba, which can be estimated at MTT 4,000,000 (total export value) minus the value of cloves and other exports produced in Zanzibar, which is estimated at MTT 100,000. The estimated value of imports is therefore MTT 6,100,000 MTT 3,900,000 = MTT 2,200,000. Such a significant drop in imports compared to the previous years and subsequent available data may be due to the bankruptcy of the French company Roux de Fraissinet, which took place in the fall of 1883. This caused serious anxiety on the market and led to the suspension of orders. Peabody Essex Museum (hereinafter: PEM), Ropes, Emmerton and Company Records, MSS 103 (hereinafter: RE), box 55, F. Cheney to Arnold Hines \& Co. and Ropes Emmerton \& Co., 28 Jan 1884, f. 3.

${ }^{45}$ Unless indicated otherwise, source: Bundesarchiv Deutschland, Abteilungen Berlin, RKA 389, E. Steifensand to Bismarck, 13 Nov 1889. 


\begin{tabular}{|c|c|}
\hline Fiscal year & Customs income \\
\hline $1884 / 85$ & 885 \\
\hline $1885 / 86$ & 810 \\
\hline $1886 / 87$ & 1,229 \\
\hline
\end{tabular}

Table 4: Share of the imports of Britain, its colonies and protectorates in total Zanzibar imports, without specie (in thousands of MTT)

\begin{tabular}{|l|c|c|c|}
\hline \multirow{2}{*}{ Fiscal year } & A & B & \multirow{2}{*}{$\begin{array}{c}\text { Percentage share } \\
\text { of A in B }\end{array}$} \\
\cline { 2 - 3 } & Total imports & $\begin{array}{c}\text { Imports of the UK, } \\
\text { British India and } \\
\text { Kutch }\end{array}$ & 41 \\
\hline $1859 / 60^{\mathrm{r}}$ & 1,702 & $708^{*}$ & 64 \\
\hline $1861 / 62^{\mathrm{p} 1}$ & 943 & 602 & 76 \\
\hline $1862 / 63^{\mathrm{p} 1}$ & 1,144 & 874 & 77 \\
\hline $1863 / 64^{\mathrm{p} 2}$ & 1,128 & 784 & 71 \\
\hline $1864 / 65^{\mathrm{se}}$ & 1,324 & 942 & 58 \\
\hline $1866 / 67^{\mathrm{k} 1}$ & 1,710 & 986 & 37 \\
\hline $1867 / 68^{\mathrm{k} 1}$ & 1,953 & 728 & 41 \\
\hline $1872 / 73^{\mathrm{hm}}$ & 1,617 & 658 & 43 \\
\hline $1873 / 74^{\mathrm{hm}}$ & 1,877 & 806 & 48 \\
\hline $1878 / 79^{\mathrm{k} 2}$ & 3,372 & $1,623^{*}$ & 68 \\
\hline $1885 / 86^{\mathrm{mc}}$ & 3,400 & $2,300^{*}$ & \\
\hline
\end{tabular}

*Estimated data.

\section{Sources used by the authors of commercial reports}

For the British, the primary source for the Zanzibar trade was data obtained from the local Customs House, which some authors clearly declared. ${ }^{46}$ In addition, the customs books have left a mark in the reports in the form of detailed tables specifying the volume of imports and exports of several dozen categories of goods along with their country or region of origin. The values constituted the basis of an ad valorem duty of $5 \%$ and other special duties. The sum of the values of imported goods resulted from adding both the values of individual products and those calculated per country or region. Both amounts add up to a common number which creates the impression of accuracy and verifiability.

${ }^{46}$ RIGBY (b), f. 239 ; PLAYFAIR1 (b), f. 178; BL, L/PS/9/51/41/1, Memorandum of Mr. Holmwood on the New Scale of Custom Duties on the Coast, 5 Feb 1875. 
While information about the volume of imports may have come from the agents of several Western companies, data on imports from India and from the coast, comprising the activities of hundreds of traders, could only be obtained from the Customs House. ${ }^{47}$

Table 5: The number of categories of imported goods in the British reports

\begin{tabular}{|l|c|}
\hline $\begin{array}{c}\text { Categories of the } \\
\text { imported goods }\end{array}$ & $\begin{array}{c}\text { Number of categories } \\
\text { of the imported goods }\end{array}$ \\
\hline RIGBY & 101 \\
\hline PLAYFAIR1 & 103 \\
\hline PLAYFAIR2 & 53 \\
\hline SEWARD & 59 \\
\hline KIRK1 & 43 \\
\hline HOLMWOOD & 44 \\
\hline KIRK2 & 24 \\
\hline
\end{tabular}

Apart from the Rigby report, all subsequent British documents of this type provide data for periods that do not correspond to full Gregorian calendar years, but rather, approximately, Zanzibari fiscal years. The reference period for debt balancing and customs duties payments fell around August 20, which coincided with the beginning of the Gujarati (and, roughly, Swahili) New Year. ${ }^{48}$ However, it cannot be ruled out that, in practice, the balance sheet of customs books was prepared a little earlier to obtain a basis for claims against debtors. The US Consul in the 1860s, Edward D. Ropes, suggested that this was done on July $31 .{ }^{49}$ While the data from the Customs House may have actually corresponded, however roughly, to the local calendars, this is not obvious in the case of data obtained from Western consulates and trading companies, whose headquarters balanced their books on a quarterly or trimester basis according to the Gregorian calendar.

It is particularly difficult to date the data contained in the Rigby report. Unlike later consular reports, Rigby labelled his statistics with

${ }^{47}$ PLAYFAIR 2, f. 890.

48 J.S. Leigh, J.S. Kirkman, “The Zanzibar Diary of John Studdy Leigh,” vol. 2, The International Journal of African Historical Studies, 13, 1980, No. 3, p. 495.

49 "In preparing statistics of the trade of Zanzibar for the past two years, I have been obliged to follow the Indian era of Kudmee or Now-roz according to which the books of the Custom-house are balanced. The years under review are, therefore, from the $1^{\text {st }}$ August 1861 , to the $31^{\text {st }}$ July 1862, and between the corresponding dates of 1862-63," PLAYFAIR 1, f. 298. 
the year 1859 without explaining what it really meant. Scholars like Nicholls and Sheriff have taken this information at face value. It is not known, however, how he could have obtained such data on imports from the Customs House. It is rather unlikely that Consul Rigby alone was adding up partial data from two subsequent (viz. 1858/59 and 1859/60) financial years. This is indicated, among other details, by the manuscript version, which includes a very extensive table of imports, probably copied directly from the customs books. ${ }^{50}$ It is therefore necessary to determine whether the data refer to the fiscal year $1858 / 59$ or rather $1859 / 60$. The fact that the Rigby report is dated July 1, 1860 suggests $1858 / 59$, as the financial year did not end until August 20. However, the Seward report drawn up five years later clearly ascribes Rigby's statistics to $1859 / 60{ }^{51}$ Therefore, it would be data for the period ending before July 1,1860 , i.e. only ten months.

In the pre-steam period, ship traffic at the Zanzibar port in July and especially in August was minimal. In addition, in 1858/59 the Zanzibar trade was heavily affected by an outbreak of cholera in the Sultanate of Zanzibar and the East African interior, which in February 1859 stopped the flow of goods from the continent for several months. ${ }^{52}$ Although these adverse effects lingered to some extent into the following financial year, I assume, in accordance with the claims of Consul Seward, that Rigby's data come from 1859/60. Rigby's description of his table suggests that the data taken from the two other consulates applied to 1859. This also may raise doubts, since French reports were always accounted for on July 1, and US reports varied between July 1 and October 1 (see Catalogue of Reports). Due to the low sea traffic in the summer, data from different reference periods in the same year should be comparable. Later British reports provide the following reference period closing dates for the data they use:

Playfair 1 (1863) - August 1

Playfair 2 (1864) - August 1

Seward (1865) - no date, but probably August 1

Kirk 1 (1870) - August 23

Holmwood (1875) - August 23

Kirk 2 (1881) - no date

${ }^{50}$ RIGBY, f. 621-631.

${ }^{51}$ SEWARD, p. 281.

52 J. Christie, Cholera Epidemics in East Africa: An Account of the Several Diffusions of the Disease in that Country from 1821 Till 1872, with an Outline of the Geography, Ethnology and Trade Connections of the Regions Through which the Epidemics Passed, London, 1876, pp. 113-115. 
Gaining access to customs books was possible with the recommendation of the Sultan, ${ }^{53}$ and probably also through personal contacts with the customs master, although there is no evidence to support such a claim. There is no indication that the Zanzibar customs records have been preserved, even in part, in any archive. These were documents of private companies who managed customs on the basis of a five-year contract, which determined the amount of the annual farm rent. Although they may have been presented for inspection by the Sultan and his ministers, it is uncertain whether this was done regularly. We know with certainty that the records were kept in Gujarati, i.e. the native language of the customs farmers and their employees. ${ }^{54}$ It should be added that there were people familiar with this language at the British Consulate. Colonel Rigby himself was a recognised expert in several Indian languages, including Gujarati..$^{55}$ Information from the customs books was not only sent to employees of the British Consulate, but occasionally also to other foreigners. It may seem that the British consuls incorporated greater insight into their books by the fact that they held jurisdiction over some, and as of the 1870s, all Zanzibar Indians. However, as we will see, access to customs books was primarily determined by the interests of the customs-farming firms, not the needs of the British Consulate.

Factors that held customs masters back from disclosing data on the Zanzibar trade include, first and foremost, the fear of the Sultan increasing the annual rent, as well as potential competitors seeking to enter the tender for the next period. There were also fears of increased competition in the sector of trade in which the farmer's company was involved..$^{56}$ This last factor mainly concerns the late period, especially the years 1876-1881, when the customs farmer was Tharia Topan, who himself was a trading tycoon. As for the Jairam Shivji company, which managed customs from the 1830s to 1876 and in 1881-1886, its tactic was rather to stimulate trade by consulting and crediting foreign merchants. The company conducted its own activity in foreign trade on a limited scale. ${ }^{57}$

53 The Sultan, questioned by the consul for trade information, sent him to the customs collector Ladha Damji. SPEER, f. 65.

54 Statistical data for 1 Oct 1863-30 Sep 1864, NARA, USCZ, reel 2, Hines to Secretary of State, 25 Oct 1864 (hereinafter: HINES2).

${ }_{55}$ Ch.P. Rigby, op. cit., p. 36.

${ }^{56}$ STAH, FO, Bd. 2, W. Schmeisser to O'Swald \& Co. 14 May 1851; STAH, FO, Bd. 3, A. H. O'Swald to O'Swald \& Co., 1 Apr 1852; STAH, FO, Bd. 10, J. Witt to O'Swald \& Co., 30 Jun 1859.

57 Centre des Archives diplomatiques du ministère des affaires étrangères, La Courneuve, France (hereinafter: CADMAE), P. 254, vol. 2, H. Jabłoński to Ministère des Affaires Étrangères (hereinafter: MAE), 7 Nov 1863, 26 Mar 1864. 
If we consider the first two of these factors, it should be presumed that data from the Customs House would be made available in the years marked by poor economic situation, and disappeared or were kept secret when Zanzibar's foreign trade flourished.

The data from the periods immediately prior to renewal of the contract, usually valid for about five years, in fiscal years 1860/61, 1865/66, 1870/71, 1875/76 and 1879/80 were particularly sensitive. There are reports describing the customs master's refusal to make customs books available to consuls in 1861,1866 and $1870 .{ }^{58}$ Data for these years, as well as those directly preceding them, do not appear in any of the British reports. Access to data from the books of 1865/66 was obtained only by the Polish emigrant Henryk Jabłoński, who was acting as French consul at that time. ${ }^{59}$ It should be noted, however, that these data are extremely unfavourable, even against the background of the 1860s. The reason for the trade crisis was the financial collapse in London in 1865, and especially in Bombay in 1866, which cut off Zanzibari Indians from orders and cash. Pessimistic data from the 1860s could have become an argument for the customs master in 1866, during negotiations regarding the extension of the farming contract for another five years. It is not entirely clear whether the British did not receive these data or preferred not to publish it. This may have been due to the weakness of the Zanzibar trade during this period, including in particular the almost complete standstill in communication with India lasting several months. ${ }^{60}$ While during the recession caused by the American Civil War the British published data for almost all years because they happened to be in their favour, information about the crisis affecting Zanzibar's trade with India would be contrary to the predominant message of the reports.

Data from the financial year 1870/71 were included in the report by the US consul Francis Webb, which encompasses the year in which the farming rent for customs was negotiated. The negotiations were

58 "The books of the Customs House must show exactly what I was most anxious to find out, but the customs master might hesitate to reveal the amount of his receipts lest at the next farming of the revenues the competition he must outbid should be alarmingly formidable." According to Speer, the Sultan demanded MTT 800,000 annually. SPEER, f. 66; CADMAE, P.254, vol. 3, H. Jabłoński to MAE, 31 Dec 1866; John Kirk wrote: "The customs master, by showing the true imports from abroad and from the African Coast, would disclose the amount of his profits, and thus draw competition into the field, while the foreign merchants have alike no desire to induce others to think of establishing rival houses," KIRK1, f. 121.

${ }^{59}$ CADMAE, P.254, H. Jabłoński to MAE, 31 Dec 1866.

${ }^{60}$ Ibid. 
among the most turbulent in history ${ }^{61}$ At the same time, it was a year of marked economic downturn, this time due to the aftermath of the cholera epidemic of 1869-1870, which ravaged East African caravan routes. ${ }^{62}$ The sum of customs revenues from the report is lower than the annual farm rent, which suggests that these data, unlike the detailed figures received by consuls in the 1860s, were an instrument in the game between Jairam Shivji and the other two claimants to take over customs management. ${ }^{63}$

The data presented in Table 2 identifies the main trends over the discussed period. The first half of the 1860s saw a crisis in Zanzibar trade caused by the American Civil War, but also by the war in the Uzaramo region, on the route supplying ivory to Zanzibar. ${ }^{64}$ However, in the second half of the decade, the market partially recovered, which allowed the level of trade in $1866 / 67$ to exceed that of $1859 / 60$. The first half of the 1870s was again marked by depression in the aftermath of, among other things, the 1872 hurricane, which almost completely destroyed clove plantations on Zanzibar. The war fought in the interior between the Mirambo state (now central Tanzania) and Arab merchants supported by the Sultanate of Zanzibar also contributed to the decrease in trade volume. ${ }^{65}$ However, the financial year 1876/77 brought about a sudden increment, as the value of foreign trade in local currency almost doubled. To some extent, it was caused by a decrease in the value of silver in relation to gold in world markets, which devalued the local currency in relation to pound sterling. ${ }^{66}$ Above all, it was influenced by the huge increase in clove prices. ${ }^{67}$ The boom lasted until the end of the decade, reaching a local high in 1877/78.

We know less about the situation in the 1880s. While the bankruptcies of some Zanzibar companies and the famine on the coast in

${ }^{61}$ National Library of Scotland (hereinafter: NLS), Acc.9942, Papers of Sir John Kirk, GCMB KCB and Lady Kirk, née Helen Cooke (hereinafter: Kirk Diary), file 25, 23 Aug 1871.

62 J. Christie, op. cit., pp. 420-434.

63 NLS, Kirk Diary, file 25, 23 Aug 1871.

64 SEWARD, p. 282.

${ }^{65}$ N. Bennett, Mirambo of Tanzania, ca. 1840-1884, New York, 1971.

66 J. Adams, R.C. West, "Money, Prices, and Economic Development in India, 1861-1895," The Journal of Economic History, 39, 1979, No. 1, pp. 55-68; K.N. Chaudhuri, "India's International Economy in the Nineteenth Century: An Historical Survey," Modern Asian Studies, 2, 1968, No. 1, pp. 31-50; S.H. Jevons, Money, Banking and Exchange in India, Simla, 1922.

${ }^{67}$ F. Cooper, Plantation Slavery on the East Coast of Africa, New Haven, 1977, p. 137. 
1883-1885 led to a collapse in trade, ${ }^{68}$ the turnover recorded in the fiscal year 1886/87 was the highest in history. The missing data on imports and exports are supplemented by data on revenue from the Customs House in the 1880s, which suggests that the crisis continued in the financial year 1885/86. This, however, contradicts the optimistic data for that year quoted by MacDonald (Table 3). Both sources indicate that the 'crisis' import values reported by MacDonald did not differ significantly from the peak results of the late 1870 s, which means that the best years in the Zanzibar trade occurred at the beginning of the 1880 s, a period from which neither import nor export data is available.

Based on the above considerations, the following conclusions can be drawn: customs farmers disclosed statistical data only if they were indicative of stagnation or recession in trade. The exceptions include $1864 / 65$, which showed a clear increase in trade as compared to the previous year. Data for the years 1876/77, 1877/78 and 1878/79 were probably handed over to Kirk by Tharia Topan after his resignation from the post of customs master, ${ }^{69}$ which explains why they were not used until the 1881 report. Data from 1885/86, published by MacDonald, were made available by the customs farmer after the administration of the Customs House had been taken over by the Zanzibari government. ${ }^{70}$ Data for the first half of the 1880 s confirm a recession in trade compared to the record levels from the turn of the 1870s and 1880 s, although the turnover was much higher than before the booming years. For the advocates of the project of greater political and military involvement of Great Britain in East Africa, such data would be a valuable argument supporting their cause. It is characteristic that Consul Kirk, who included in his diaries all the statistical data on international trade of Zanzibar he had obtained, did not publish those that covered the period 1880-1885.

The table of the Customs House's income (Table 3) indicates that, although the annual farm rent for that period was MTT 500,000 - the highest in history - the farmer still made a profit. Some doubts may be raised by the fact that the previous farmer had voluntarily given up the extension of the contract for a lower rent of MTT 50,000. However, at the beginning of the 1880s, the potential competition for the Customs House contract could include not only Indian companies, but

${ }^{68}$ PP, 1884-85, C.4523/103/4, Kirk to Earl Granville, 24 Oct 1884; PP, 1886, C.4776/108, Kirk to Earl Granville, 14 Feb 1885.

${ }^{69}$ Ch. Goswami, The Call of the Sea. Kachchhi Traders in Muscat and Zanzibar, c. 1800-1880, New Delhi, 2011, p. 228.

70 MACDONALD, f. 9. 
also the Scottish shipping tycoon William Mackinnon, who in the 1870s tried to take over the Customs House administration by offering the Sultan much better conditions. ${ }^{71}$ From 1885, an even more important factor prompting both the Sultan and Jairam Shivji to keep information secret was the annexation of extensive areas of the hinterland of today's Tanzania by the German company DOAG, which received the so-called protection letter (Schutzbrief) of the German emperor. As it soon turned out, DOAG also claimed access to the coast. ${ }^{72}$

Certainly, Western consuls in Zanzibar borrowed data from each other, drawing information from publications or, more often, directly from the other officials. This was certainly a widespread practice in the 1860s. Both William Speer and Edward Hines openly admitted in their reports that their data had been taken from British colleagues - Rigby and Playfair, respectively. ${ }^{73}$ In the report of Edward D. Ropes Senior, containing, among other details, a long-term summary of aggregated data on imports and exports of individual countries (for 1859-1865), the data for 1859-1864 are no different from those of Rigby and Playfair, although the author did not mention his source. Instead, he stated that he had gained knowledge about trade through his own efforts, including information from the Customs House. Indeed, the data for financial year 1864/65 differ from those in the Seward report and can be considered completely original. These are not only aggregated data, but also a detailed list of imports and imports by country, unique for US reports. Consular officials would continue to borrow trade data in the later years. Consul MacDonald wrote in 1887, for example, that he had been asked to share his data with a German colleague. The request was granted..$^{74}$

Tables 6 and 7 depict data on trade between France and Zanzibar, as well as the US and Zanzibar, in the 1860s, derived from British, French and US reports. When it comes to imports, and in part exports of these two countries, a clear convergence can be noticed between French and British data. The slight differences can be explained by the shift in reference period. US data on its own imports and exports are

${ }^{71}$ M. Pawełczak, The State and the Stateless. The Sultanate of Zanzibar and the East African Mainland: Politics, Economy and Society, 1837-1888, Warsaw, 2010, p. 332 .

${ }^{72}$ R. Coupland, The Exploitation of East Africa, London, 1939, p. 470.

${ }^{73}$ Speer referred to independently obtained data from the Customs House, but published the data from the Rigby report. SPEER, f. 65. NARA, USCZ, reel 2, E. Hines to W. Seward, 24 Dec 1863 (hereinafter: HINES1), n.p.

${ }^{74}$ MACDONALD, f. 10. 
Table 6: Comparison of data on the trade of France with Zanzibar in 1859-1865 based on British and French data (in thousands of MTT)

\begin{tabular}{|c|c|c|c|c|}
\hline \multirow{2}{*}{ Fiscal year } & \multicolumn{2}{|c|}{ Imports } & \multicolumn{2}{c|}{ Exports } \\
\cline { 2 - 5 } & British & French & British & French \\
\hline $1859 / 60$ & $116^{\mathrm{r}}$ & $168^{\mathrm{f} 59}$ & $247^{\mathrm{r}}$ & $131^{\mathrm{f} 59}$ \\
\hline $1861 / 62$ & $9^{\mathrm{p} 1}$ & $5^{\mathrm{f} 2}$ & $139^{\mathrm{p} 1}$ & $195^{\mathrm{f} 62}$ \\
\hline $1862 / 63$ & $19^{\mathrm{p} 1}$ & $20^{\mathrm{f} 63}$ & $187^{\mathrm{p} 1}$ & $199^{\mathrm{f} 63}$ \\
\hline $1863 / 64$ & $34^{\mathrm{p} 2}$ & $51^{\mathrm{f} 64}$ & $236^{\mathrm{p} 2}$ & $270^{\mathrm{f64}}$ \\
\hline $1864 / 65$ & $152^{\mathrm{se}}$ & $55^{\mathrm{f} 65}$ & $258^{\mathrm{se}}$ & $284^{\mathrm{f65}}$ \\
\hline
\end{tabular}

Table 7: Comparison of data on the trade of France and the US with Zanzibar (excluding specie) in 1859-1874. Based on British, US and French data (in thousands of MTT)

\begin{tabular}{|c|c|c|c|c|c|c|}
\hline \multirow{2}{*}{$\begin{array}{c}\text { Fiscal } \\
\text { year }\end{array}$} & \multicolumn{3}{|c|}{ Imports } & \multicolumn{3}{|c|}{ Exports } \\
\hline & GB & US & Fr. & GB & US & Fr. \\
\hline $1859 / 60$ & $568^{\mathrm{r}}$ & $1,255^{\mathrm{s}}$ & n.d. & $534^{\mathrm{r}}$ & $1,216^{\mathrm{s}}$ & n.d. \\
\hline $1861 / 62$ & $82^{\mathrm{p} 1}$ & $160^{\mathrm{s}}$ & $72^{\mathrm{f62}}$ & $104^{\mathrm{p} 1}$ & $109^{\mathrm{s}}$ & $105^{\mathrm{f62}}$ \\
\hline $1862 / 63$ & $92^{\mathrm{p} 1}$ & $91^{\text {h1 }}$ & $97^{f 63}$ & $134^{\mathrm{p} 1}$ & $186^{\mathrm{h} 1}$ & $196^{\mathrm{f63}}$ \\
\hline $1863 / 64$ & $42^{\mathrm{p} 2}$ & $45^{\mathrm{r} 1}$ & $44^{\mathrm{f} 64}$ & $304^{\mathrm{p} 2}$ & $304^{\mathrm{r} 1}$ & $303^{\mathrm{f64}}$ \\
\hline $1864 / 65$ & $138^{\mathrm{se}}$ & $65^{\mathrm{r} 1}$ & $60^{f 65}$ & $86^{\mathrm{sw}}$ & $75^{\mathrm{r} 1}$ & $56^{665}$ \\
\hline $1865 / 66$ & n.d. & $196^{\mathrm{r} 2+}$ & $291^{\mathrm{f} 66}$ & n.d. & $692^{\mathrm{r2} @}$ & $133^{\mathrm{f} 66}$ \\
\hline $1866 / 67$ & $297^{\mathrm{k} 1}$ & $256^{\mathrm{r} 2+}$ & $320^{\mathrm{f} 67}$ & n.d. & $702^{\mathrm{r} 2 \#}$ & $573^{f 67}$ \\
\hline $1867 / 68$ & $311^{\mathrm{k} 1}$ & n.d. & $357^{f 68}$ & n.d. & n.d. & $447^{\mathrm{f68}}$ \\
\hline $1872 / 73$ & \multirow{2}{*}{$619^{\mathrm{hm} \S}$} & n.d. & n.d. & \multirow{2}{*}{$1,246^{\mathrm{hm} \S}$} & $838^{\S}$ & n.d. \\
\hline $1873 / 74$ & & n.d. & n.d. & & $656^{\S}$ & n.d. \\
\hline
\end{tabular}

* Excluding cargo shipped aboard British ships (about 186,000 thalers in total); @ Refers to 1866; \# Refers to the period June 1-30, 1867; + Excluding specie; $§$ Total for both years.

much higher than that for Britain and France. As noted earlier, the reports from the 1870s do not take into account the trade of individual countries. Holmwood's report provides data on the imports and exports of the two largest US companies operating in Zanzibar (i.e. about 90\% of the total US volume) for the years $1872 / 73$ and 1873/74. A comparison of the export data from Holmwood's report with the sum calculated on the basis of invoices collected by the US Consulate in Zanzibar for goods shipped by US companies during this period indicates that in this case the British data are significantly underestimated (Table 7).

This does not necessarily mean that the US consuls did not disclose their data to their British and French colleagues. Their data could be based on declarations of US vessels leaving Zanzibar and export invoices 
certified at the consulate. The declarations of US captains obviously would not include goods exported through the use of foreign vessels. During the American Civil War, US companies with agencies in Zanzibar used the services of British ships, especially when they sent goods to the US, but this practice continued after the war. Quarterly statements from the turn of 1865 and 1866 that compare the imports and exports of US and foreign ships have been preserved. They show that in terms of value, just like during the war, exports on foreign ships exceeded those on US ships.

The data for a sample quarter is presented in Table 8 below. Consuls Playfair and Seward apparently used only data received from ship captains. It should be added that they did not mention that the statistics concerning each individual country only included cargoes shipped onboard vessels sailing under the respective country's flag. It is unlikely that the consuls were unaware of the transport of US goods on British ships. This form of data presentation reflects the typical British belief at the time that the volume of a country's trade was measured by the number and tonnage of its merchant fleet, at least in terms of the value of imported and exported items. However, the authors of the reports chose this method of presenting data because it better showed the leading position of the trade of Great Britain and its possessions. In the steamer era, the difference between US exports on foreign and US-owned ships was much greater. ${ }^{75}$

Table 8: Imports and exports of US companies operating in Zanzibar in the period of July-September 1866 (in US dollars) ${ }^{76}$

\begin{tabular}{|l|r|r|}
\hline Ships by the country of origin & Imports & Exports \\
\hline US ships & 188,887 & 122,877 \\
\hline Other ships & 26,000 & 138,669 \\
\hline
\end{tabular}

\section{Reliability of export and import data}

The shortcoming of customs books as a source of information on international trade was undoubtedly the lack of data on exports from Zanzibar. As exports were not subject to duties or taxation, records were not necessary. ${ }^{77}$ Charges were assessed on goods transported from the East African coast to Zanzibar, that is on internal imports of the Sultanate.

\footnotetext{
${ }^{75}$ BACHELDER, f. 36.

76 NARA, USCZ, Reel 2.

77 PLAYFAIR1, p. 297.
} 
This means that of the main exported goods, only cloves, coconuts (both whole and processed), and sugar produced on the island were not recorded in the customs books. However, this does not pose a serious problem for researchers, because the volume of clove crops, as well as their prices, were usually widely known and commented upon, a topic often reflected in the reports. ${ }^{78}$ However, we do not know the volume of the products which were imported to Zanzibar from overseas that were not sold there, and had to be shipped, for example, to Bombay. In some years, these could have involved substantial amounts of goods. ${ }^{79}$

As mentioned earlier, the British obtained information on exports from the consulates of the US, France and Hamburg, as well as Western trade agents and employees of the Customs House. The latter were well-acquainted with this subject, even despite the lack of export controls. The greatest doubt was raised by the degree to which commercial agents of these countries were willing to inform consuls who might have been their competitors. There is evidence that US consuls were also not fully informed about the volume of exports onboard US ships leaving Zanzibar. The revenue laws of the United States required that the US consul certify invoices for goods on the basis of which the ad valorem duty was to be paid. However, in practice this regulation was not observed in the $1840 \mathrm{~s} .^{80}$ While in the 1880 s it was still assumed that agents were obliged to do so, few of the small companies operating in the Zanzibar market at that time respected the rule. ${ }^{81}$ Based on invoices presented by shippers, the consul prepared detailed quarterly ship traffic statements. When leaving the port, vessels flying the flag of the United States were not subjected to any consular control. ${ }^{82}$ Some sources refer to notes about the tonnage and value of the cargo sent to the consulate before leaving the port, but the consuls usually did not examine them. Consul Speer was convinced that the information received via the notes was, in principle, understated "for obvious commercial reasons." $\$ 3$ The same problem was signalled by British consul John Kirk in the report from $1870 .^{84}$

${ }^{78}$ M. Pawełczak, op. cit., p. 320.

${ }^{79}$ PEM, Michael Shepard Papers, MH 23 (hereinafter: Shepard Papers), box 14, Ch. Ward to M. Shepard, 5 Jan 1851, f. 5.

80 “Ch. Ward to US State Department, 21 Feb 1846," New England..., p. 355.

${ }^{81}$ NARA, USCZ, reel 4, Bachelder to US State Department, 4 Jan 1884.

82 “W.E. Hines to W.H. Seward, 25 Oct 1864," New England..., p. 526.

${ }^{83}$ SPEER, f. 68.

84 "It is impossible to obtain accurate and reliable statistics of the trade of Zanzibar, everyone being interested in representing the imports and exports less than they actually are.” KIRK1, f. 121. 
Table 9: Imports and exports of specie in the period 1859-1865 (in thousands of MTT). Based on: SEWARD, f. 283-284

\begin{tabular}{|l|c|c|c|c|c|}
\hline & $\mathbf{1 8 5 9}$ & $\mathbf{1 8 6 1 / 6 2}$ & $\mathbf{1 8 6 2 / 6 3}$ & $\mathbf{1 8 6 3 / 6 4}$ & $\mathbf{1 8 6 4 / 6 5}$ \\
\hline Import & 750 & 321 & 377 & 286 & 309 \\
\hline Export & 370 & 385 & 243 & 360 & 335 \\
\hline
\end{tabular}

The problems posed by the method of presentation of the Zanzibar trade are fully revealed in the Rigby report. It included the category 'bullion' in its export and import statistics, which increased the total turnover by almost $30 \%$. In subsequent reports, until 1865, this practice was continued, although Consul Seward compiled the full value of the import and export of bullion for the entire period 1860-1865, except for 1860/61 (see Table 9). In addition, by double-counting imports and exports within the state of Zanzibar, the consul exaggerated the actual trade turnover. Following the usage of the Customs House, he included in the category of 'imports' goods transported from the East African coast to Zanzibar, which provided the largest number (over $\$ 363,000$, while US imports, ranking second, amounted to over $£ 126,000)$. As the result of the inflated statistical data, in terms of trade volumes Zanzibar presented itself as a trade centre at least equivalent with Aden and Karachi during a similar period. The aggregate import to export ratio of Zanzibar (numbers rounded to whole thousands) was 909:756 (see Table 10 below, which is informed by the Rigby report). However, after subtracting the imports from and exports to East Africa (£364,000 and $£ 274,000$, respectively) the proportion would be around 545:482, i.e. there was a much smaller, though still significant advantage of imports to East Africa over exports from the region.

As suggested above, it was widely believed that the value of exports was underestimated in reports because consuls and agents of trading companies were not always interested in disclosing their turnover.$^{85}$ Furthermore, the underestimation of exports can be further attributed to the imperfections of the customs collection system. At the end of the 1840s, a French ministerial officer delegated to study East African trade wrote about high levels of smuggling. ${ }^{86}$ In addition, the Zanzibar Customs House was believed to engage in concealing data on the actual export of goods to Zanzibar, or the customs farmer did not provide the true and accurate data on this subject.

${ }^{85}$ STAH, FO, Bd. 2, W. Schmeisser to O'Swald \& Co., 14 May 1851.

${ }^{86}$ Archives Nationales d'Outre Mer, Aix-en-Provence, France, FM SG 5/23-2, Cpt. Loarer, Lois et coutumes de Douanes. Commerce sous les divers Pavillons. 
The customs collector in Mombasa in the 1870s told a British Consulate official that the data on exports from the port to Zanzibar was underreported by a third..$^{87}$

Table 10: Trade of individual countries and regions with Zanzibar from the report of Colonel Rigby (for the fiscal year 1859/60) ${ }^{88}$

\begin{tabular}{|c|c|c|c|c|c|c|c|c|c|}
\hline \multirow{2}{*}{ Countries } & \multicolumn{3}{|c|}{ Imports from } & \multicolumn{3}{|c|}{ Exports to } & \multicolumn{3}{|c|}{ Total } \\
\hline & $£$ & s. & $\mathrm{d}$. & $£$ & s. & $\mathrm{d}$. & $£$ & s. & d. \\
\hline Great Britain & \multicolumn{3}{|c|}{ n.d. } & 5,566 & 15 & 0 & 5,686 & 15 & 0 \\
\hline United States & 236,398 & 16 & 0 & 118,688 & 18 & 0 & 245,087 & 14 & 0 \\
\hline France & 114,790 & 18 & 0 & 55,000 & 0 & 0 & 169,790 & 18 & 0 \\
\hline Hamburg & 101,296 & 18 & 0 & 35,777 & 15 & 0 & 137,074 & 13 & 0 \\
\hline British India & 99,606 & 15 & 0 & 105,888 & 18 & 0 & 205,495 & 13 & 0 \\
\hline Kutch & 57,872 & 0 & 0 & 69,664 & 10 & 0 & 127,536 & 10 & 0 \\
\hline Singapore & 7,895 & 0 & 0 & \multicolumn{3}{|c|}{ n.d. } & 7,895 & 0 & 0 \\
\hline Arabia & 17,666 & 19 & 0 & 23,377 & 14 & 6 & 40,984 & 13 & 6 \\
\hline East coast of Africa & 363,666 & 15 & 0 & 274,200 & 0 & 0 & 637,866 & 15 & 0 \\
\hline West coast of Africa & \multicolumn{3}{|c|}{ n.d. } & 51,111 & 2 & 6 & 51,111 & 2 & 6 \\
\hline Madagascar & 19,777 & 14 & 0 & 16,411 & 2 & 0 & 36,188 & 16 & 0 \\
\hline Total & 908,911 & 15 & 0 & 755,686 & 15 & 0 & $1,664,598$ & 10 & 0 \\
\hline
\end{tabular}

Total Zanzibar exports should equal the sum of imports from East Africa, the value of goods produced and exported from Zanzibar, as well as exported coins. Using the data in the table above, this can be expressed by the following equation:

$$
\mathrm{E}=\mathrm{I}+\mathrm{Z}+\mathrm{B}
$$

where: E stands for Zanzibar exports; I refers to imports from the coast of East Africa and Pemba to Zanzibar; Z represents the sum of the value of goods produced in Zanzibar and exported overseas; and B is the value of exported coins.

Therefore, $\mathrm{Z}=\mathrm{E}-\mathrm{I}-\mathrm{B}$.

Rigby estimated the export of coins from Zanzibar to $£ 82,000,89$

therefore: $\mathrm{Z}=482-364-82=36$ (data rounded to thousands of pounds).

However, the consul estimated the total value of clove production at about $£ 56,000$, of which about $£ 45,000$ of cloves came from Zanzibar.

${ }^{87}$ HOLMWOOD, f. 236.

${ }_{88}$ Aggregated data in British reports from the 1860s and from 1881 are given in pounds sterling.

${ }^{89}$ RIGBY, f. 645. 
The value of coconuts produced and exported from Zanzibar, including copra, cannot be accurately estimated since most were consumed in Zanzibar..$^{90}$ It is also important to consider vegetable oils and oilseeds, which, according to the Rigby report, could have been worth up to $£ 15,000$. If we assume that Rigby's data on imports and exports come from similar reference periods, the above reasoning would indicate that the value of exports from Zanzibar for 1859/60 was greater than the report claims by at least $£ 24,000$.

The underestimation of exports in the long-term period is shown in Table 11 below. In the 1860s, the value of goods imported to Zanzibar from the East African coast obtained on the basis of Customs House data constituted from over $70 \%$ to over $130 \%$ of the value of exports from Zanzibar estimated by British consuls. Such large deviations can be attributed to the storage of goods and disparate accounting periods for imports and exports. Therefore, data from individual years cannot lead to any categorical conclusions. The long-term average shows an underestimation of exports at the level of $4 \%$, which, with uncertain estimates of the value of exports of coconuts, oilseeds and vegetable oils, is insignificant.

Table 11: The ratio of the value of imports from the East African coast to the estimated value of exports of these goods from Zanzibar (in thousands of MTT)

\begin{tabular}{|l|c|c|c|c|c|c|}
\hline \multicolumn{1}{|c|}{ Year } & A & $\mathbf{B}$ & $\mathbf{C}$ & $\mathbf{D}$ & $\mathbf{F}=\mathbf{B}-\mathbf{C}-\mathbf{D}$ & $\mathbf{A} / \mathbf{F}$ (\%) \\
\hline & $\begin{array}{c}\text { 'Imports' } \\
\text { from the } \\
\text { coast and } \\
\text { Pemba to } \\
\text { Zanzibar }\end{array}$ & $\begin{array}{c}\text { Overseas } \\
\text { exports } \\
\text { from Zanzi- } \\
\text { bar }\end{array}$ & $\begin{array}{c}\text { Approximate } \\
\text { value of Zan- } \\
\text { zibar-grown } \\
\text { cloves (80\% of } \\
\text { the total East } \\
\text { African crop) }\end{array}$ & $\begin{array}{c}\text { Exports of } \\
\text { Zanzibar- } \\
\text { grown coco- } \\
\text { nuts and oil } \\
\text { seeds }\end{array}$ & $\begin{array}{c}\text { Overseas export } \\
\text { from Zanzi- } \\
\text { bar adjusted } \\
\text { for estimated } \\
\text { production of } \\
\text { cloves, coconuts, } \\
\text { oilseeds and } \\
\text { vegetable oil }\end{array}$ & \\
\hline $1859 / 60$ & $1,633^{\mathrm{r}}$ & $1,799^{\mathrm{r}}$ & 200 & 60 & 1,539 & 106 \\
\hline $1861 / 62$ & $517^{\mathrm{p} 1}$ & $988^{\mathrm{p} 1}$ & 161 & 102 & 725 & 71 \\
\hline $1862 / 63$ & $927^{\mathrm{p} 2}$ & $1,102^{\mathrm{p} 1}$ & 266 & 143 & 693 & 133 \\
\hline $1863 / 64$ & $1,818^{\mathrm{p} 2}$ & $2,219^{\mathrm{p} 2}$ & 165 & $200^{*}$ & 1,854 & 98 \\
\hline $1864 / 65$ & $1,264^{\mathrm{sw}}$ & $1,429^{\mathrm{sw}}$ & 252 & $100^{*}$ & 1,077 & 117 \\
\hline $1867 / 68$ & $1,527^{\mathrm{k} 1}$ & $1,856^{\mathrm{k} 1}$ & 240 & $100^{*}$ & 1,516 & 100 \\
\hline $\begin{array}{l}\text { Six-year } \\
\text { average }\end{array}$ & 1,281 & & & & 1,234 & 104 \\
\hline
\end{tabular}

* Estimated data.

${ }^{90}$ PLAYFAIR1, f. 327. 
However, when we take into account the average values of imports and exports of selected products imported from the coast (Table 12), we see that imports of cowhides and the orchilla weed (raw material for indigo dye) from the coast are significantly underestimated, which confirms imperfections within the customs system. In the case of copal and ivory, the surplus of imports is understandable. Copal typically lost up to $50 \%$ of its weight in the cleaning process (known as garbling). As for ivory, parts of a tusk not suitable for export were rejected. It should be added that ivory and copal were goods bringing both the customs farmer and the Sultan particularly high revenues from customs duties. Each piece of ivory was registered and marked at a Customs House in one of the coastal ports and then transported to Zanzibar, where it was the importer who most often paid the duty. Since a central record of imported tusks was kept, the illegal import and sale to a foreign recipient were quite difficult. ${ }^{91}$ This explains why the discrepancy between average long-term imports and exports is moderate.

Table 12: Imports from the coast and overseas exports of selected products in 18591865 (in thousands of MTT; based on SEWARD, f. 283-284)

\begin{tabular}{|c|c|c|c|c|c|c|c|c|c|c|c|c|}
\hline Year & \multicolumn{2}{|c|}{$1859 / 60$} & \multicolumn{2}{|c|}{$1861 / 62$} & \multicolumn{2}{|c|}{$1862 / 3$} & \multicolumn{2}{|c|}{$1863 / 4$} & \multicolumn{2}{|c|}{$1864 / 5$} & \multicolumn{2}{|c|}{$\begin{array}{c}\text { Five-year } \\
\text { average }\end{array}$} \\
\hline Product & 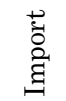 & 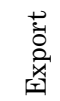 & 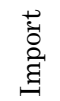 & 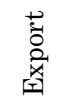 & $\begin{array}{l}\stackrel{0}{0} \\
\stackrel{0}{\Xi}\end{array}$ & 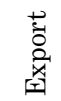 & 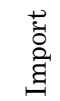 & 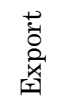 & 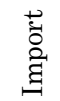 & 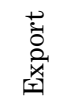 & 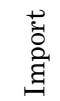 & 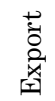 \\
\hline Copal & 150 & 13 & 150 & 103 & 200 & 160 & 135 & 163 & 110 & 72 & 158 & 110 \\
\hline Ivory & 883 & 312 & 30 & 309 & 277 & 197 & 682 & 930 & 552 & 618 & 468 & 451 \\
\hline $\begin{array}{l}\text { Cattle } \\
\text { hides }\end{array}$ & 80 & 115 & 18 & 49 & 14 & 93 & 30 & 36 & 20 & 35 & 32 & 66 \\
\hline Orchilla & n.d. & n.d. & 60 & 7 & 65 & 74 & 50 & 91 & 65 & 34 & 58 & 58 \\
\hline
\end{tabular}

The above analysis of the content of the reports indicates that there was a loophole in the customs system, but only less valuable goods leaked through. This most likely had little impact on the records of imports from the coast of East Africa. It should be added that in the 1870 s and 1880 s the customs system was tightened, ${ }^{92}$ which may have partially eliminated smuggling, but not necessarily embezzlement by customs officers. On the other hand, the low estimates of overseas exports from Zanzibar do not prove the underestimation of imports

91 “W.E. Hines to W.H. Seward, 25 Oct 1864," New England..., p. 527.

${ }_{92}$ M. Pawełczak, op. cit., p. 306. 
from the coast. ${ }^{93}$ This is surprising, bearing in mind the shortage was believed to amount to, in terms of value, one-third of what actually reached Zanzibar. It seems impossible to prove the existence of this gap if the consuls, attempting to best balance the coastal data they received, lowered their assessments of overseas exports. The fact that the reports drawn up from 1870 onwards no longer include such tables at all seems to support the thesis that overseas exports were underestimated in previous years.

All the above considerations do not take into account the discrepancy between the price declared by the Customs House and the price paid by commercial agents to Zanzibari brokers. While much of the trade took place at the Zanzibar Customs House, which helped officials determine the amount of import duties, some higher quality batches of goods were sold for amounts largely exceeding the average price. This price could be determined in a private auction or negotiation. It was not until 1886, when a government official took over the operation of the Customs House to eliminate this shortcoming, that importers were ordered to sell ivory solely by public auction. The highest bid determined the amount of duty. ${ }^{94}$

One should also take into consideration the reliability of data on overseas imports. Here, some of the problems clearly resulted from the imperfections of the customs system. Many traders came on sailing boats from India, which made it impossible to collect reliable data on imports..$^{95}$ In addition, Western ships arriving in Zanzibar were not required to submit customs declarations. After leaving the port, the recipient of the goods, whenever he had time to spare, called the customs agent at home and they jointly determined the amount of duty. As US Consul Hines wrote, "the highest trust is placed in the integrity and honesty of a white man and I do not think that this trust has ever been abused." 96 While some observers indicate that Western importers lowered the value of invoices, the customs master, even if he rejected the declared value, was satisfied with a slight correction. ${ }^{97}$ Presumptions about undervaluation on invoices were allegedly confirmed

93 Jan Czekanowski mentions tolerance among Indian entrepreneurs for minor misappropriations of their agents. See: J. Czekanowski, W gtab lasów Aruwimi. Dziennik wyprawy do Afryki Środkowej, Wrocław, 1958, p. 170.

${ }^{94}$ PEM, RE, box 57, Cheney to Arnold Hines \& Co. and Ropes Emmerton \& Co., 12 May 1884, f. 4; PEM, RE, box 58, E. Ropes to A. Cheney, 14 Mar 1887, f. 3.

95 CADMAE, P. 254, vol. 2, H. Jabłoński to MAE, 2 Feb 1862.

96 “W.E. Hines to W.H. Seward, 25 Oct 1864," New England..., p. 526.

${ }_{97}$ NLS, Kirk Diary, file 25, 30 Sep 1872. 
by the fact that the duty, which in theory could be adjusted in kind, was almost always paid in cash. ${ }^{98}$ This was despite the fact that the merchants were permanently short of cash. The duty was calculated based on the invoice presented by the importer plus a certain percentage of the value of the goods as the cost of import. In the second half of the 1870 s this was $20 \%$, but in 1881 Jairam Shivji started charging $35 \%$. After an attempt to pay this duty in kind, in one reaction to the increase a commercial agent informed the British Consulate that it was troublesome because the boxes had to be opened in the Customs House, which enticed thieves. Also, deducting exactly 5\% of the goods was sometimes difficult to carry out and might result in a loss for the importer. ${ }^{99}$

\section{Summary and conclusions}

This text is meant to be the first step towards a critical study of consular data on the Zanzibar trade in the second half of the nineteenth century. By using a broad range of sources, it demonstrates the usefulness of British trade reports for studying general trade trends. The analysis suggests that they are also a valuable source for understanding changes in the trade structure, as well as more specific categories and issues. With the use of an extensive critical apparatus, as well as materials produced outside Zanzibar (including India), there is a chance to make a breakthrough in knowledge about the international trade of a country for which it was the basic raison d'être.

The fact that the consular reports contain mostly data for the years of commercial stagnation does not discard their value. The economic downturn was normal in Zanzibar-like economies, that is, strongly dependent on many unstable factors. The Zanzibar trade was exposed to risks related to local conditions (e.g. patency of caravan routes, shortage of rain, epidemic diseases) as well as global circumstances (e.g. wars, financial crises, price fluctuations). By reviewing the trade correspondence of Western merchants, one can get the impression that they permanently struggled with lack of cash and problems with the supply of export products or the demand for imported goods. Even consular trade reports leave no doubt that the mostly unprofitable 1860s and early 1870s were followed by years of boom, though subsequent

\footnotetext{
98 SPEER, f. 54.

${ }_{99}$ Zanzibar National Archives (ZNA), AA 2/31, Amerback to Miles, 19 Oct 1881.
} 
'crises' brought much greater turnover than the best periods of the $1860 \mathrm{~s}$, mainly due to the transport revolution.

The above analyses show that from the point of view of the British consuls, customs data were of fundamental importance for determining the size and structure of trade. Even despite their declared efforts, the consuls used other sources in a limited and perhaps also incompetent way. Relying on customs sources obviously had a rational basis: even if they contained incomplete and inaccurate data, they reflected the overall structure of trade and trends. Exports overseas largely depended on imports from the interior and the coast. Clearly, some of the poorer quality products were stored in Zanzibar in anticipation of price increases. From this point of view, paradoxically, 'internal export' customs data bearing in mind their permanent undervaluation - are as valuable as import data, as overseas import control was also unreliable.

It is not possible to determine the index by which the data from the Customs House should be increased. However, we can assume that the effectiveness of the customs system in combatting smuggling increased with the growth in the number of customs posts on the coast and the number of staff employed. Therefore, the import data of the 1870 s and 1880s may be considered more reliable than those from earlier decades. On the other hand, if local collectors continued to underreport data, the expansion of the customs system could have led to more extensive distortions, as more officers may have carved out a portion of the profits. When it comes to overseas imports, there are no references to steamships being controlled more strictly than was the case for sailing dhows. We can only guess that it was easier to regulate the unloading of one large ship than several dozen smaller ones of similar total tonnage, which suggests the greater reliability of statistics from the steamship period.

The use of consular sources gave consuls a chance to correct the customs data, but it took some fluency to interpret them. In early periods, when British consuls received aggregate statistics from their colleagues, they did not always know what they represented: total imports of merchant companies from a given country or imports on ships from a given country. Even if we give credence to US consulate data, which contain estimates two or three times higher than the British records, it still does not mean that we should correct the total amount of Zanzibar imports by the difference. This discrepancy may represent the value of British goods imported by the US and should be deducted from the data on British imports. Perhaps this is due to the awareness that an attempt to represent detailed import data from the Customs House in national 
categories would distort reality without bringing any positive knowledge. Certainly the reports from the 1870s are more competent than those of the 1860s, but one cannot resist the reflection that the increase in awareness of the subtleties of the Zanzibar trade in the 1880s led to the decline of the production of consular reports rather than their revival. The reason was that embracing the full knowledge of trade in the steam era simply grew more and more difficult.

Separating the statistics from the general narrative is a challenge awaiting all researchers of consular reports. Statistical data played a persuasive role, serving as an appendix to communications and not the other way around. This, of course, does not mean that data subverting the general narrative did not sneak into the reports, which is especially true of their full, unpublished versions from the 1860s. However, one should not assume that consuls falsified data as a general rule. Rather, it was the method of data preparation and presentation that did not allow for the illustration of the full level of complexity of international trade and those of its aspects that did not fit the overarching message, which stressed the importance of British trade and industry, as well as the role of Zanzibar in the political system of India.

Since virtually no direct British trade was carried out with Zanzibar at the beginning of the period considered, the reports focused on Indian merchants who imported British goods from India. This could lead the reader to the wrong conclusion that they traded mainly in British goods, and imported goods that were ultimately intended for the British market. In the 1870s, when it seemed that objective factors, such as greater credit opportunities and better circulation of information, should favour British companies, the participation of Indians in the Zanzibar trade increased to unexpected heights. While the British consular staff did not lack knowledge or passion in exploring the problems of the Zanzibar trade, these issues were not sufficiently reflected in trade reports. It was not until the 1880s that the British consulate revealed some degree of contradiction between the interests of Indian and British merchants, although the official reports do not mention the actual competition between the textile industries of the two countries. The reason for this was political and was associated with the, at the time, fluid concept of British rule in the Indian Ocean. The idea that India would find its own approach to expansion in this region would not emerge until a few years later. 


\section{Bibliography}

\section{Catalogue of consular reports used in the article}

In parentheses: the label used in the footnotes, the link used in the Tables. Unless stated otherwise, this is the version marked below as "a."

\section{British Reports}

The report of Colonel Christopher Rigby of 1860 (RIGBY, r)

a.) BL, IOR/L/PS/9, vol. 37, Ch. Rigby to Earl Russell, 1 Jul 1860, f. 597-655.

b.) PP, 1863, 3229, Report by Lieutenant-Colonel C. P. Rigby, Her Majesty's Consul and British Agent, on the Trade of Zanzibar, for the Year 1860, [n.d.], pp. 239-249.

c.) "Report on the Zanzibar Dominions, by Lieutenant-Colonel C.P. Rigby, Bombay Army, Her Majesty's Consul and British Agent at Zanzibar," in: Ch.P. Rigby, General Rigby, Zanzibar and the Slave Trade: With Journals, Dispatches etc., ed. by Ch.E.B. Russell, London, 1935, pp. 326-355.

The report of Robert Playfair of 1863 (PLAYFAIR1, p1)

a.) BL, IOR L/PS/9/41, Playfair to Russell, Administration Report of the Zanzibar Political Agency for the Year Ending 31 May 1864, 1 May 1864, f. $297-329 . .^{100}$

b.) PP 1864, 3393, R. Playfair, 20 Dec 1863, pp. 178-182.

The report of Robert Playfair of 1864 (PLAYFAIR2, p2)

BL, IOR L/PS/9/42, R. Playfair to C. Gonne, Administration Report of Zanzibar for the Year 1864-64, 17 Apr 1865, f. 881-893.

The report of George Seward of 1865 (SEWARD, se)

PP, 1867, 3761, Report by Mr. Acting Consul Seward on the Trade and Commerce of Zanzibar for the year 1864-5, [n.d.], pp. 281-288.

The report of John Kirk of 1870 (KIRK1, k1)

NA, FO/84 1344, J. Kirk, Administration report of the Zanzibar Agency, 1870, Rendered July 18, 1870, f. 116-166.

The report of Frederick Holmwood of 1875 (HOLMWOOD, hm)

NA, FO/84/1415, Prideaux to Earl Derby, 8 Feb 1875, f. 202-256.

The report of John Kirk of 1881 (KIRK2, k2)

NA, FO/84/1657, Report by Consul Kirk on the trade and Commerce of Zanzibar for the year 1881, 21 Apr 1882, f. 11-24.

100 Oddly, the cover letter for the report is dated one month earlier than the end date of the accounting period. 
The report of Claude MacDonald of 1887 (MACDONALD, mc)

NA, FO/403/104/10, Major C.M. MacDonald to Marquis Salisbury, 19 Dec 1887, f. 9-11.

\section{American Reports}

The report of William Speer (SPEER, s)

Statistical data drawn from the Rigby report.

NARA, USCZ, reel 2, W.J. Speer, Consular Report, 26 Nov 1862.

The report of Edward Hines of 1863 (HINES1, h1)

Statistical data for 1 Oct 1862-31 Jul 1863

NARA, USCZ, reel 2, E. Hines to W. Seward, 24 Dec 1863.

The report of Edward Hines of 1864 (HINES2, h2)

Statistical data for 1 Oct 1863-30 Sep 1864, NARA, USCZ, reel 2, Hines to Secretary of State, 25 Oct 1864. See also the published version: "W.E. Hines to W.H. Seward, 25 Oct 1864," in: New England Merchants in Africa: A History Through Documents 1802 to 1865, ed. by N. Bennett, G. Brooks, Boston, 1965, p. 526.

The report of Edward Ropes Sr. of 1865 (ROPES1, r1)

Statistical data for 1 Aug 1864-31 Jul 1865

NARA, USCZ, reel 2, E. D. Ropes to W. Seward, 5 Oct 1865.

The report of Edward Ropes Sr. of 1867 (ROPES2, r2)

Statistical data for 1 Jul 1865-30 Jun 1867 (only the US trade)

NARA. USCZ, reel 2, E.D. Ropes Sr. to W. Seward, 15 Aug 1867.

The report of Francis Webb of 1871 (WEBB, w)

Statistical data for 1 Oct 1870-30 Sep 1871 (no breakdown by country)

F. Webb, "Report on the Commerce of Zanzibar for the Year Ending September 30, 1871, 12 Nov 1871," in: House of Representatives, Annual Report on the Commercial Relations between the United States and Foreign Nations Made by the Secretary of State for the Year Ending September, 30, 1872, Washington, 1873, pp. 704-707.

The report of Leonard Bachelder of 1880 (BACHELDER, b)

No date, but uses statistical data from the Zanzibar customs books (no breakdown by country)

L. Bachelder, "Trade of Zanzibar," in: House of Representatives, Report upon the Commercial Relations of the United States with Foreign Nations for the Years 1880 and 1881, Washington, 1882, pp. 33-36. 
Report of Frederick Cheney (CHENEY, ch)

NARA, USCZ, reel 4, Cheney to Third Assistant of the Secretary of State, 1 Jul 1884. See also a published version: Statistical data for 31 Dec 1883 -30 Jun 1884 (only the US trade), in: E.D. Ropes Jr., The Zanzibar Letters of Edward D. Ropes, Jr., ed. by N. Bennett, Boston, 1979, pp. 119-123.

\section{French Reports}

CADMAE, P. 254

L. Cochet to MAE, 31 Dec 1859 (f. 59)

M. Derche to MAE, 31 Dec 1860 (f. 60)

H. Jabłoński to MAE, 31 Dec 1862 (f. 62)

H. Jabłoński to MAE, 31 Dec 1863 (f. 63)

H. Jabłoński to MAE, 31 Dec 1864 (f. 64)

H. Jabłoński to MAE, 31 Dec 1865 (f. 65)

H. Jabłoński to MAE, 31 Dec 1866 (f. 66)

H. Jabłoński to MAE, 31 Dec 1867 (f. 67)

E. Bure to MAE, 31 Dec 1868 (f. 68)

\section{Literature}

Adams J., R.C. West, "Money, Prices, and Economic Development in India, 1861-1895," The Journal of Economic History, 39, 1979, No. 1, pp. 55-68.

Bennett N., A History of the Arab State of Zanzibar, London, 1978.

Bennett N., Mirambo of Tanzania, ca. 1840-1884, New York, 1971.

Chaudhuri K.N., "India's International Economy in the Nineteenth Century: An Historical Survey," Modern Asian Studies, 2, 1968, No. 1, pp. 31-50.

Christie J., Cholera Epidemics in East Africa: An Account of the Several Diffusions of the Disease in that Country from 1821 till 1872, with an Outline of the Geography, Ethnology and Trade Connections of the Regions Through which the Epidemics Passed, London, 1876.

Cooper F., Plantation Slavery on the East Coast of Africa, New Haven, 1977.

Coupland R., The Exploitation of East Africa, London, 1939.

Czekanowski J., W głab lasów Aruwimi. Dziennik wyprawy do Afryki Środkowej, Wrocław, 1958.

De Goey F., "Consuls and the Institutions of Global Capitalism, 1783-1914," Perspectives in Economic and Social History, 2016, No. 34 (e-book).

Figuring African Trade: Proceedings of the Symposium on the Quantification and Structure of the Import and Export and Long Distance Trade in Africa, 1800-1913, ed. by G. Liesegang, H. Pasch, and A. Jones, Berlin 1986 (Kölner Beitrage zur Afrikanistik, 11).

Galbraith J.S., Mackinnon and East Africa 1878-1895: A Study in the 'New Imperialism', Cambridge, 2009.

Giffen R., "The Use of Import and Export Statistics," Journal of the Statistical Society of London, 45, 1882, No. 2, pp. 181-296. 
Goswami Ch., The Call of the Sea. Kachchhi Traders in Muscat and Zanzibar, c. 1800-1880, New Delhi, 2011.

Hahner-Herzog I., Tippu Tip und der Elfenbeinhandel in Ost- und Zentralafrika im 19. Jahrhundert, München, 1990.

Jevons S.H., Money, Banking and Exchange in India, Simla, 1922.

Leigh S., Kirkman J.S., "The Zanzibar Diary of John Studdy Leigh, Part II," The International Journal of African Historical Studies, 13, 1980, No. 3, pp. 492-507.

Mézin A., "Les services consulaires français au XIX ${ }^{\mathrm{e}}$ siècle," in: Consuls et service consulaires au XIXe siècle. Consulship in the $19^{\text {th }}$ Century. Die Welt der Konsulate im 19. Jahrhundert, ed. by J. Ulbert, L. Prijac, Hamburg, 2010, pp. 47-61.

New England Merchants in Africa: A History Through Documents 1802 to 1865, ed. by N. Bennett, G. Brooks, Boston, 1965.

Nicholls Ch.S., The Swahili Coast. Politics, Diplomacy and Trade on the East African Littoral 1798-1856, London, 1971.

O'Rourke K.H., Williamson J.G., Globalization and History. The Evolution of a Nineteenth-Century Atlantic Economy, Cambridge (MA), 2000.

Pawełczak M., The State and the Stateless. The Sultanate of Zanzibar and the East African Mainland: Politics, Economy and Society, 1837-1888, Warszawa, 2010.

Prestholdt J., Domesticating the World. African Consumerism and the Genealogies of Globalization, Berkeley, 2008.

Rigby Ch.P., General Rigby, Zanzibar and the Slave Trade: With Journals, Dispatches etc., ed. by Ch.E.B. Russell, London, 1935.

Ropes E.D. Jr., The Zanzibar Letters of Edward D. Ropes, Jr., ed. by N. Bennett, Boston, 1979.

Sheriff A., Slaves, Spices and Ivory in Zanzibar. Integration of an East African Commercial Empire into the World Economy, 1770-1873, London, 1987.

Suzuki H., "Enslaved Population and Indian Owners Along the East African Coast: Exploring the Rigby Manumission List, 1860-1861," History in Africa, 39, 2012, pp. 209-239.

Marek Pawełczak

Statistical data on international trade in British consular reports from the Sultanate of Zanzibar in the nineteenth century

(Summary)

The article investigates the reliability of nineteenth-century British consular reports as a source for studying international trade in Zanzibar. The author compares statistical data contained in the reports with the political narrative assigned thereto. He also collates British trade data with information coming from reports from the United States and France, as well as the 
correspondence of American and German trading companies operating in East Africa. The author concludes that the data from the British reports derives from essentially reliable sources, primarily from now lost Zanzibar customs books. Due to restrictions on access to these sources, British diplomats were given insight into them only under specific conditions, and almost exclusively during the years of economic downturn. British data on the French and, most significantly, American involvement in the Zanzibar trade often correlate to data from the local diplomatic posts of these countries. However, they should be confronted with additional preserved documents. Although few inconsistencies can be found in the data contained in the reports, it is likely that they include significant underestimations, though this does not preclude a significant degree of credibility in terms of trade structure and general trends. In the 1860s the method of presenting data exaggerated the importance of Zanzibar as a trade centre and overstated the role of Great Britain and India in Zanzibar trade. In the 1870 s, along with the increase in methodological difficulties posed by data analysis, greater accuracy and the elimination of less reliable estimates led to the growing brevity of the reports, and even to the decline of such documents in the 1880s.

Marek Pawełczak - ur. 1967, historyk Afryki Wschodniej i Oceanu Indyjskiego, doktorat z historii uzyskany w 1999 r. na Uniwersytecie Warszawskim. Adiunkt na Wydziale Historii Uniwersytetu Warszawskiego. Autor m.in. The State and the Stateless. The Sultanate of Zanzibar and the East African Mainland: Politics, Economy and Society, 1837-1888, Warsaw, 2010.

Marek Pawelczak - born 1967, historian of East Africa and the Indian Ocean, $\mathrm{PhD}$ in History, 1999, University of Warsaw. Associate Professor at the Department of History of the University of Warsaw. Author of, inter alia, The State and the Stateless. The Sultanate of Zanzibar and the East African Mainland: Politics, Economy and Society, 1837-1888, Warsaw, 2010.

E-mail: m.pawelczak@uw.edu.pl. 